\title{
A PEDAGÓGUSKÉPZÉSBE INTEGRÁLT MULTIKULTURALIZMUS, AZ AKKREDITÁCIÓS KÖVETELMÉNYEK SZELLEMÉBEN
}

\author{
PILLANATKÉP AZ EGYESÜLT ÁLLAMOKBÓL
}

\section{SZÉCSI TÜNDE}

a Florida Gulf Coast University egyetemi docense (Fort Myers, FL)

tszecsi@fgcu.edu

\begin{abstract}
Angliában Az USA közoktatásában részt vevö diákok növekvö arányban képviselik az etnikai, nyelvi és vallási kisebbségi csoportokat. Ezek a demográfiai változások jelentősen módosítják az oktatás szociokulturális hátterét, és igy a pedagógusképző intézeteknek is számos kihívással kell szembenézniük. Ezen intézmények minőségbiztositását a Pedagógusképzők Nemzeti Akkreditációs Tanácsa (NCATE) végzi. A következö irás összefoglalja az NCATE multikulturalizmusra vonatkozó követelményeit, valamint ismerteti egy dokumentumelemzés eredményeit. Az elemzés kimutatta azokat a hatékony értékelési/mérőeszközöket, amelyeket egy pedagógusképzö program a multikulturális ismeretek, készségek és attitüdök mérésére használ.
\end{abstract}

\section{A pedagógusképzés szociokulturális háttere: demográfiai változások az USA közoktatásában}

Az elmúlt negyven évben az Egyesült Államokban jelentős társadalmi és oktatáspolitikai változások mentek végbe a legális és illegális bevándorlások és a kisebbségi csoportok polgárjogi mozgalmainak következtében. Ezeknek eredményeként, a közoktatásban az 5-18 éves iskolás korosztály demográfiai összetétele erőteljesen változik. Jelenleg a diákok mintegy $40 \%$-a a kisebbséghez tartozik, mivel a többségtől eltérő etnikai, kulturális, nyelvi, vallási és szociális háttérrel rendelkeznek. Ha a statisztikai előrejelzések helyesek, akkor 2035-re a diákok több mint fele az angolszász, fehér középosztálytól eltérő családban nő fel (Hodgkinson, 2002).

Míg a kisebbségi diákok száma évről-évre emelkedik, addig a velük foglalkozó kisebbségi pedagógusok aránya 9\%-ra csökkent (Torres és mtsai, 2004). A közoktatásban dolgozó pedagógusok 90\%-a fehér európai-amerikai, középosztálybeli; nagy része nő, és az angolon kívül más nyelvet nem beszél. A pedagógusképzésben oktatók demográfia háttere is hasonló, azaz szociokulturális hátterük nagyban megegyezik a pedagógusjelöltek 90\%-val, vagyis fehér középosztályhoz tartoznak (American Association of Colleges for Teacher Education, 1999). 
A demográfiai adatok túlmutatnak a számokon. Megerősítik azt, hogy a kisebbségi csoportokhoz tartozó tanulók és a többségi (fehér, angolszász középosztály) csoporthoz tartozó pedagógusok kulturális háttere, referenciarendszere eltér, ahogy Gay fogalmaz. „különbözően létező valóságokban” élnek (Gay, 1993, 13. o.). Így a pedagógusok ritkán válnak hiteles példaképpé a kisebbségi kultúrából származó gyerekek számára. Továbbá, a kutatások szerint, a pedagógusok jelentős része nem rendelkezik az eltérő kultúrákra vonatkozó ismeretekkel és a másság kezeléséhez szükséges pedagógiai kompetenciákkal. Mindez meggátolhatja azt, hogy a kisebbségi tanulók olyan oktatási-nevelési programban vehessenek részt, amely összhangban áll az otthoni kultúrájukkal és korábbi élettapasztalataikkal. Ezen felül, a pedagógusok jelentős százaléka elöítéletes nézeteket vall a kisebbségi tanulókról, és nem érez felelősséget és hajlandósságot a megváltozott pedagógus szerep vállalására (Banks, 2006). Az eltérő kultúrákból adódó különbözőségeket mint hátrányt, hiányt érzékelik, és csökkentett elvárásaik negatívan hatnak a tanulók iskolai teljesítményére (Gay és Howard, 2000).

A helyzet összetettségét fokozza a közoktatásban megfigyelhetö esélyegyenlöség hiánya. Az oktatásban-nevelésben rendelkezésre álló segédeszközök, valamint a tanárok végzettsége és felkészültsége jóval alacsonyabb az olyan iskolákban, ahol jelentősebb számban vannak a kisebbségi diákok. Továbbá a tanulók iskolai teljesítményére hatással van kultúrájuk, etnikai hovatartozásuk, anyanyelvük és szociális helyzetük. Azaz a fekete (afrikai-amerikai) és a spanyol ajkú (föként Latin Amerikából bevándorolt) diákok szövegértési és matematika eredménye messze elmarad a fehér (többségi) diákok eredményétől; valamint e két kisebbségi csoport tagjai között a legmagasabb azoknak a diákoknak a száma, akik nem végzik el a középiskolát. Villegas és Lucas (2002) ezt úgy interpretálja, hogy a jelenlegi közoktatási rendszer alkalmatlan arra, hogy hatékonyan oktassa és nevelje a kisebbségi diákokat.

Mindez arra figyelmeztet, hogy a pedagógusképzésben fontos változásokra volt és van szükség, és ugyanakkor az is egyértelmü, hogy a kizárólag a pedagógusképzésben végbemenő változások nem adnak tökéletes gyógyírt az amerikai közoktatás problémájára.

\section{A multikulturális komponens a pedagógusképzésben: variációk egy témára}

A társadalmi változások okozta kihívásokra a pedagógusképző programok számos programmódosítással válaszolnak. Az általános cél, hogy a pályakezdő pedagógusok felkészültek legyenek a különböző kultúrájú diákok oktatására és nevelésére, valamint a multikulturalizmust, mint értéket fogadtassák el mind a többségi, mind a kisebbségi gyerekekkel. A pedagógusképzés multikulturális komponense több szinten, formában és minőségben valósul meg. A szakirodalom számtalan multikulturális tantervi próbálkozást vizsgál, amelyek között szerepelnek, az egy-két napos intenzív mühelyfoglalkozások $(X u, 2000)$, az önálló, kötelező multikulturális 
kurzus terepgyakorlattal (Mason, 1999), valamint az összes kurzust érintő programszintủ integrálás. A programszintü integrálás akkor valósul meg, amikor az öszszes kurzus - gyermeklélektan, pedagógia és módszertani kurzus - foglalkozik azzal, hogy felkészítse a hallgatókat a különböző háttérrel rendelkező diákok oktatására, függetlenül attól, hogy irodalom vagy matematika tantárgyról van szó. A későbbiekben ismertetendő vizsgálat egy olyan pedagógusképző program keretében folyt, ahol a multikulturális komponenst programszinten integrálták azzal a céllal, hogy az állami és össznemzeti akkreditációs feltételeknek megfeleljenek.

\section{A multikulturalizmussal kapcsolatos NCATE követelmények (Standard 4)}

A pedagógusképző programok minőségellenőrzése az állami és a össznemzeti akkreditációs folyamatok során zajlik. A legmagasabb szintủ és presztizsủ akkreditációs intézmény a Pedagógusképzők Nemzeti Akkreditációs Tanácsa (NCATE), amelynek célja a pedagógusképző programok minőségbiztosítása. Jelenleg az USA-ban mintegy 700 pedagógusképző főiskola és egyetem bizonyította az NCATE által elfogadott minőségi mutatók (standard) teljesítését (National Council for Accreditation). Az NCATE teljesítményalapú akkreditációs rendszerében, az intézmények dokumentálják, hogy a 6 minőségi mutatót (standard) kielégítő, illetve kimagasló szinten érvényesítik, és ennek köszönhetően magasan képzett pedagógusjelöltek végeznek a programban.

Az NCATE hat minőségi mutatója közül a Standard 4 a mássággal/multikulturalizmussal kapcsolatos elvárásokat fogalmazza meg. Eszerint, az intézménynek olyan pedagógusképző programot kell kidolgozni, alkalmazni és értékelni, amely a tanárjelöltet felvértezi olyan tudással, készséggel és attitüddel, hogy képes legyen hatékonyan elősegíteni minden gyerek tanulási folyamatát, függetlenül attól, hogy kisebbségi csoporthoz tartozó-e vagy sem. A pedagógusképző programban használt értékelési/mérörendszernek egyértelmüen jeleznie kell, hogy a pedagógusjelöltek képesek gyakorlatban is használni az eltérő kultúrák kezeléséről elsajátított tudást, készségeket és attitüdöt. Továbbá az is követelmény, hogy a pedagógusképzés multikulturális környezetben valósuljon meg, ahol mind az oktatók, mind a diákok képviselik a kulturális és nyelvi sokszínüséget; valamint gyakorlatban is alkalmazzák ezeket, azaz a tanítási gyakorlat során kisebbségi gyereket is oktatnak.

A Standard 4 Másság/Multikulturalizmus minőségi mutatón belül négy alszempont szerepel, amelyeknek kielégítő célteljesítéséhez a következőket kell dokumentálni (National Council for Accreditation):

1) Programtervezés, alkalmazás, értékelés és tapasztalatok más kultúrákkal: A pedagógusképző intézmény programja egyértelmüen meghatározza a másságra vonatkozó kompetenciákat, amelyeket a hallgatók a program során elsajátítanak, és a gyakorlati tanítás idején demonstrálnak. Ezeket a más- 
ságra vonatkozó kompetenciákat értékelik, és az értékelés alapján a pedagógusjelölt visszajelzést kap. A kompetenciák magukba foglalják a következőket: a pedagógusjelölt a) figyelembe veszi a diákok különböző tanulási stílusát, és ennek alapján alkalmazza a tanítási stratégiák széles skáláját, b) összehangolja a tananyag megközelítését a diákok korábbi élettapasztalatával, kultúrájával, c) a szülőkkel és diákokkal folytatott kommunikáció során figyelembe veszi a kulturális és nemek szerinti eltéréseket, d) képes kialakítani olyan egyenlő esélyeket biztosító tanulási-tanítási környezetet, ahol minden részvevő értékként ismeri el a másságból adódó sokszínüséget.

2) Tapasztalatszerzés a kisebbséghez tartozó oktatókkal: A pedagógusjelöltnek (mind a hagyományos, mind a távoktatási formában) lehetősége van olyan oktatókkal dolgozni, akik legalább két etnikai csoportot képviselnek, és rendelkeznek a másságra (kulturális, nyelvi és képességbeli) vonatkozó ismeretekkel és tapasztalatokkal. Továbbá, a pedagógusképző program minden erőfeszítést megtesz, hogy az oktatók között legyenek a másságot, kisebbségi csoportokat képviselő oktatók.

3) Tapasztalatszerzés a kisebbséghez tartozó pedagógusjelöltekkel: A pedagógusjelölt (mind a hagyományos, mind a távoktatási formában) olyan oktatási és tanulási folyamatokban vesz részt, ahol együttmüködik a különböző szociális helyzetủ és legalább két etnikai csoport hallgatóival. A pedagógusképző program minden erőfeszítést megtesz, hogy a hallgatók között legyenek férfi és nő hallgatók, valamint különböző szociális helyzetü és legalább két etnikai csoportot képviselő pedagógusjelöltek.

4) Tapasztalatszerzés a kisebbségi csoportokhoz tartozó diákokkal (5-18 éves korosztály): A tanítási gyakorlat lehetőséget nyújt a pedagógusjelöltnek, hogy tapasztalatot szerezzen a hátrányos szociális helyzetü és legalább két különböző etnikai csoporthoz tartozó diákokkal, valamint fejleszthesse a nem-angol anyanyelvü és a speciális igényekkel rendelkező tanulókról alkotott ismereteit, készségeit és hozzáállását. A mentortanártól és a társaktól kapott visszajelzés elősegíti a pedagógusjelölt reflektív önértékelését.

Az akkreditációs folyamat során a pedagógusképző programoktól megkövetelik, hogy értékelési és mérőrendszerük az előzőekben felvázolt követelményeket mérjék. A pedagógusképző programok értékelési/mérörendszere a programot alkotó összes kurzus úgynevezett kritikus feladataiból (esszé, kiselőadás, óraterv, tanmenettervezet, interjú) áll össze. A pedagógusképző programban a pedagógusjelölt sikeresen elvégzi ezeket a kritikus feladatokat, ami egyben azt is dokumentálja, hogy a program az NCATE követelményeinek megfelel. 


\section{Szemelvények egy pedagógusképző program értékelési/mérőrendszeréből az NCATE Standard 4 követelményének tükrében}

A vizsgálat tárgyául egy akkreditációra készülő pedagógusképző Bachelor (alapfokú) programot választottam. Azt vizsgáltam, hogy a programban szereplő kurzusok értékelési/mérőeszközei (például esszé, óraterv, reflektív feljegyzés, interjú) milyen lehetőséget biztosítanak a NCATE Standard 4 első és negyedik alpontjából meghatározott kompetenciák mérésére.

A vizsgálatban szereplő Bachelor program az 5-12 éves korosztály tanítására képez pedagógusokat, specializálódás nélkül. A 126 kreditórás program (1 kreditóra kb. 50 perces órának megfelelö) magában foglalja a 60 kreditórányi általános kurzusokat (General Education), azaz matematika, természettudományok, müvészetek, társadalomtudományok és kommunikáció; és 66 kreditórányi pedagógiai, gyermekfejlödéstani és módszertani kurzust. Beépítet, kötelező komponensként, az itt végzett hallgatók megszerzik a nem angol anyanyelvü diákok oktatásához szükséges müveltségterületi képesítést (endorsement) is.

A vizsgálat adatait a 66 kreditórát alkotó, 22 kurzus tanmenete szolgáltatta, amelyet dokumentumelemzéssel értelmeztem. A tanmeneteket átvizsgálva, valamennyi olyan értékelési/mérőeszközt kiválasztottam, amely utalt a multikulturalizmusra. Ezeket továbbvizsgáltam aszerint, hogy elméleti megközelítést vagy gyakorlati alkalmazást; illetve ismeretet, képességet és/vagy attitüdöt mérnek. A továbbiakban részletesen négy értékelési/méröeszközt ismertetek, amelyekröl az elemzés kimutatta, hogy az NCATE multikulturalizmusra vonatkozó követelményeit a legteljesebb mértékben integrálják és értékelik.

Kisebbségi diákról szóló környezettanulmány interjú alapján: A pedagógusjelöltek 3-4 fős csoportja adatokat gyüjt és értelmez egy kisebbségi diák (nem angolul beszélö, hátrányos szociális helyzetü), tanulási környezetéről és az iskolai és iskolán kívüli tanulással kapcsolatos tapasztalatairól. A szülővel, a kisdiákkal és a pedagógussal folytatott beszélgetések és óralátogatások alapján a pedagógusjelöltek próbálják feltérképezni a szülők iskolával kapcsolatos elvárásait, a kisebbségi kultúrából adódó speciális igényeket, és az iskola ezen igényekre szabott szolgáltatásait. E környezettanulmány keretén belül a pedagógusjelölt kilép saját kultúrájának komfort zónájából, és a kisebbségi kultúráról szerzett ismerten kívül valós élethelyzetben próbálja ki, hogy mennyire képes a kultúrák közötti kommunikációra. Az adatok értelmezését egy esszében és egy kiselőadásban teszik közzé, amelyeket a professzor és a társak értékelnek.

Multikulturális irodalom olvasása reflektív napló vezetésével: A pedagógusjelölt elolvas három szépirodalmi müvet (gyermek, ifjúsági és felnőtt irodalom), amelyek egy kisebbségi kultúrával foglalkoznak, például a Puerto Rico-i családok. Az olvasás során reflektív naplót vezet, ahol a könyvekben szereplö új, meglepö vagy különös ismeretekről, gondolatokról reflektív módon értekezik. Ezt követően, 
a reflektív naplóban arról is vall, hogyan fogja a gyakorlatban használni azokat az ismereteket, készségeket és hozzáállást, amelyeket a könyvek olvasása során elsajátított. Az írásos munkán kívül csoportmegbeszélés keretén belül megismerkednek a más hallgatók által olvasott kultúrákról, illetve a pedagógiai alkalmazásról ötleteket cserélnek.

Egyéni igényekre épülö oktatás (15 óra gyakorlat egy nem angol anyanyelvü diákkal). A pedagógusjelölt kiválaszt egy angol nyelvet második nyelvként tanuló diákot (LEP Limited English proficient student), hogy egyéni formában, azaz egyéni igényre szabott feladatokkal segítse a kisdiákot az angol nyelv elsajátításában. A mentortanár segíti a pedagógusjelöltet a feladatok kiválasztásában és a tanítási folyamatban, valamint értékeli a heti 3 órában, öt héten keresztül végzett gyakorlat alatt. Közben a pedagógusjelölt reflektív módon értelmezi saját munkáját, a kisdiák sikereit és nehézségeit és az összeállított, alkalmazott feladatok hatékonyságát. Végezetül, a pedagógusjelöltek számára megfogalmazott állami sztenderdek alapján reflektív összegzést ír az elsajátított és demonstrált kompetenciákról.

Befogadó nevelésre alkalmas tanitási-oktatási környezet és programtervezés és óraterv. A pedagógusjelöltek 3-4 fös csoportja megtervez egy befogadásos nevelésre alkalmas iskolai környezetet, programot és óraterveket. Az iskolai környezet megtervezésekor figyelembe veszik a speciális igényü kisdiákokat. A pedagógiai program összeállításakor megfogalmazzák a hátrányos szociális helyzetü, nem angol anyanyelvü, illetve eltérő vallású gyerekek igényének megfelelő módosításokat, szolgáltatásokat. A programtervezethez csatolt valamennyi óraterv tartalmaz egy részt, ahol a differenciált foglalkozásra vonatkozó konkrét tervet kell csatolni, hogy az adott tantervi cél eléréséhez hogyan segítik hozzá a valamilyen szempontból speciális igényü diákokat. Ezeket az óraterveket később, a gyakorló tanítás során a valóságban is alkalmazzák, és a mentortanár értékeli, hogy a pedagógusjelölt milyen mértékben képes a kisebbségi gyerekek oktatására és nevelésére.

\section{Összegzés}

Ahogy az USA közoktatásában résztvevők demográfiai háttere változik, úgy módosulnak a pedagógusképző programok elé állított kihívások és elvárások. Az eltérő etnikai, kulturális és szociális háttérrel rendelkező diákok hatékony tanításáranevelésére olyan pedagógusok vállalkozhatnak, akik ismeretekkel, készségekkel és megfelelő attitüddel rendelkeznek a multikulturális nevelésről. Ezek meglétének értékelésére a pedagógusképzők olyan értékelési/mérörendszert használnak, amely az akkreditációs intézmények követelményeit mérik. Ez az írás ismertette egy pedagógusképző program legmarkánsabb mérőeszközeit, amelyek a másságra és multikulturalizmusra vonatkozó készségeket hivatottak mérni és az NCATE akkreditációs követelményeknek megfelelően dokumentálni. 


\section{Irodalom}

American Association of Colleges for Teacher Education. (1999). Teacher education pipeline IV. Schools, colleges, and department of education enrollment by race, ethnicity, and gender. Washington, DC: Author

Banks, J. A. (2006): Cultural diversity and education. Boston: Pearson.

Gay, G. (1993): Building cultural bridges: A bold proposal for teacher education. Education and Urban Society, 25(3), 285-289.

Gay, G., Howard, T. (2000): Multicultural teacher education for 21 st century. Teacher Educator, 36(1), 1-16.

Hodgkinson, H. (2002): Demographics and teacher education. Journal of Teacher Education, 53(2), 102-105.

Mason, T. C. (1999): Urban field experience and prospective teachers' attitudes toward inner-city schools. Teacher Education Quaterly, 24(3), 29-40.

National Council for Accreditation of Teacher Education. Retrived September 25, 2008 from http://www.ncate.org.

Torres, J., Santos, J., Peck N., Cortes, L. (2004): Minority teacher recruitment, development, and retention. Providence, RI: The Education Alliance at Brown University.

Villegas, A., Lucas, T. (2002): Educating culturally responsive teachers. A coherent approach. Albany, NY. SUNY Press.

$\mathrm{Xu}, \mathrm{H}$. (2000): Preservice teachers integrate understanding of diversity into literacy instruction: An adaptation of the ABC's model. Journal of Teacher Education, 51, 135-142. 